\title{
CONSEQUENCES OF ENVIRONMENTAL MANAGEMENT ACCOUNTING (EMA): THE THEORY BEHIND
}

\author{
Dr. Avylin Roziana Mohd Ariffin \\ Faculty of Economics and Muamalat \\ Universiti Sains Islam Malaysia \\ Malaysia
}

\section{ABSTRACT}

\begin{abstract}
The need for Environmental Management Accounting (EMA) can be associated with the major problems of environmental degradation that lead to other concerns, such as legitimacy and competitive issues. EMA is seen as a management accounting innovation whose consequence is a boost to corporate performance. EMA can benefit the competitive position of a firm by directing the attention of its managers towards potential cost reduction or potential areas for differentiation. EMA can also help firms gain resource productivity and process efficiency, which will result in the reduction of waste and improved the financial profitability of the firm. In other words, EMA practically improves both the environmental and economic performance of a firm. However, despite all these success stories, many firms are still reluctant to take a more proactive approach to EMA, perhaps due to a perceived lack of evidence that the benefits exceed the costs of pursuing these initiatives. The findings so far may also not be generalizable since they are based on descriptive statistics rather than rigorous hypothesis testing. There has been little empirical evidence regarding the impact of EMA on the business success of the firm. This is due to prior EMA studies that have made limited use of a theory that attempts to explain the consequences of the practice. Most research has focused on descriptive work and researchers seem to be unwilling to move beyond action-based case studies in further develop the framework of EMA practice and firm performance. This has raised a concern on the need for theoretical explanation on the consequences of EMA. As it is important to gauge the effects of EMA on firm performance, this study provides a discussion of how EMA could help companies in Malaysia to enhance both their economic and environmental performance and by this to encourage firms to put EMA in practice for their sustainable growth.
\end{abstract}

\section{Keywords: EMA, Environmental Management Accounting, NRBV, Green Accounting}

\subsection{INTRODUCTION}

Despite the increased concerns of the community on environmental issues, companies still fail to actively engage in environmental management (Christ \& Burritt, 2013; Gadenne \& Zaman, 2002) because they are uninformed about their environmental impacts and the costs to the company and lack an efficient system to provide relevant information (Ditz, Ranganathan \& Banks, 1995; Gale, 2006b; Russell, Skalak \& Miller, 1994). Potentially, management accounting facilitates firms' recognition of and appropriate response to environmental issues. However, it has not only failed to address environmental issues but also inhibited changes by focusing on performance measures that maintain the status quo and discourage experimentation (Atkinson et al., 1997; Baines \& Langfield-Smith, 2003). Conventional systems, especially the costing and investment appraisal system, have failed to support new technologies and have significantly handicapped their implementation (Askarany, Smith \& Yazdifar, 2007; Bruggeman \& Slagmulder, 1995; Doorasamy \& Garbharran, 2015). Management and accounting information systems can respond to environmental responsibilities by providing adequate support for information needs and decision making (Dillard, Brown \& Marshall, 2005). The traditional management accounting system particularly could be modified to incorporate environment-related information to support managers' needs and to aid companies to design environmentally preferable processes, products, and services that will lead to improved environmental performance and business success (USEPA, 1995). Environmental Management Accounting (EMA) is seen as a management accounting innovation whose consequence is a boost to corporate performance. EMA can benefit the competitive position of a firm by directing the attention of its managers towards potential cost reduction or potential areas for differentiation. EMA can also help firms gain resource productivity and process efficiency, which will result in the reduction of waste and improved the financial profitability of the firm. In other words, EMA practically improves both the environmental and economic performance of a firm.

\subsection{LITERATURE REVIEW}

This section will look at previous research on EMA, focusing on how EMA could be linked to the business performance of a firm. The first section will present some thoughts on the importance of the EMA system to be associated with other management accounting tools to enhance both corporate's environmental performance and economic performance. This is followed by a discussion on several 


\section{(C) Center for Promoting Education and Research (CPER) USA}

www.cpernet.org

theoretical perspectives that might explain the link between EMA and business performance.

\subsection{Consequences of EMA}

Up to date, there have been many studies focusing on particular EMA methods and the consequences of having them applied in business. This section will discuss how EMA can be linked to environmental management processes and it will present some selected practical cases on the application of various EMA tools in various settings.

The implementation of EMA is expected to enhance the quality of decision making and plays a significant role in supporting the application of green technologies such as Cleaner Production (CP) (Staniskis \& Stasiskiene, 2006; Willshurmst \& Frost, 2001). To make decisions to invest in green technologies, companies have to look at the cost of production, processes, products, and activities from an environmental perspective. However, this requires procedures and a framework beyond what is currently being offered by a conventional management accounting system. The current system does not take into consideration the environmentalrelated information while calculating for investment projects' inflow and outflow, which may distort the overall decision process (Russel et al.,1994). Such constraints produce inaccurate costing on which companies base their operational decisions, making new technologies unattractive to be invested in because their costs and benefits are not apparent (Gale, 2006b; Staniskis \& Stasiskiene, 2006). This is very detrimental to companies, since technologies such as $\mathrm{CP}$ signal efficient production. $\mathrm{CP}$ which reduces pollution at the source using cleaner products and cleaner production methods is superior to end-of-pipe technologies (Schaltegger, Burritt, Bennett \& Jasch, 2008; Frondel et al., 2007). In contrast to a traditional accounting system, the EMA approach can demonstrate the real potential of each investment alternative and further justify the application of green technologies. A study by USEPA (1995) on 29 companies in the highly polluting organic chemical industry found that chemical plants that applied some type of environmental cost accounting program have an average of three times as many pollution prevention (P2) projects as plants with no environmental cost accounting system. This has led to 1.6 million pounds of waste being reduced for each P2 project, which is equal to an average savings of $\$ 3.49$ for every dollar spent (USEPA, 1995). The use of EMA information in investment appraisal also assists companies to decide wisely on alternatives that further lead to an improved firm performance (Burritt et al., 2009; Deegan, 2003a). A more recent study by Schaltegger, Viere, and Zvezdov (2012) adds evidence on the suitability of EMA to support $\mathrm{CP}$ in developing countries. Based on the case study of Sai Gon Beer in Vietnam, the authors describe how EMA application improves the existing environmental management systems by breaking down the physical inputs and outputs to production steps and supply processes, which has led to the identification of several alternatives for improvement.

EMA is also a practical tool for Environmental Management System (EMS) implementation; by planning, implementing, and evaluating the response of the business towards environmental concerns, accountants can help companies to successfully implement EMS. EMS involves a formal system and database that integrate procedures and processes for personnel training, monitoring, summarizing, and reporting environmental performance information to internal and external stakeholders of the firm (Melnyk, Sroufe \& Calantone, 2003). Its purpose is to develop, implement, manage, coordinate, and monitor corporate environmental activities to achieve legal and regulatory compliance and to reduce waste (Sayre, 1996). The growth of EMS has been rapid ever since the introduction of ISO 14001 in 1996 (Iraldo, Testa \& Frey, 2009). ISO 14001 is a certified EMS that provides a third-party guarantee of a company's environmental excellence and indicates that the company is actively committing itself to improve its environmental performance (Iraldo et al.,2009). The scheme is becoming a dominant international standard for assessing environmental management processes and may grant an advantaged position to organizations. Companies that wish to remain competitive in the industry are employing EMS, as indicated by the increasing number of ISO 140001 certified firms around the globe (ISO, 2008). However, to develop EMS and get it certified, a procedural improvement at the firm level is needed since EMS demands more and better record keeping and documentation to lead to improved control (Morrow \& Rondinelli, 2002). Complete information is necessary to monitor progress towards objectives and quantify improvements once companies have set their environmental goals. The integration of a cost accounting system into the environmental information system has been the key for companies' quantification of the real costs and benefits of environmental programs (Gadenne \& Zaman, 2002; Russel et al., 1994), and EMA supports the compilation and analysis of relevant environmental information required by EMS. Utilization of EMA tools for investment appraisal, costing systems, budgets and performance measures facilitate the reinforcement, maintenance, and provision of a sounder EMS (Albelda, 2011; Perez, Ruiz \& Fenech, 2007).

Much of the literature revolves around the use of EMA as a tool for environmental management, the majority of studies using a case study approach to examine the implementation of various EMA tools in various types of organizations. Among the studies are Onishi, Kokubu, and Nakajima (2008), who researched Tanabe Seiyaku Co. Limited, a pharmaceutical company in Japan. Their study focused on the technological aspects of Material Flow Cost Accounting (MFCA), that is, what has been the company's practice, and discusses how this practice can be continuously 


\section{(C) Center for Promoting Education and Research (CPER) USA}

www.cpernet.org

employed. This study is among a number that demonstrates the successful use of EMA in mitigating environmental impact and providing greater economic efficiency to companies practicing it. The authors find that there are two important requirements for MFCA is to be continued. First, MFCA cannot be used as a stand-alone technique but should be combined with other management control techniques and with management control systems such as Enterprise Resource Planning (ERP), so that all material flow cost data can be incorporated into the financial information system. This is consistent with the recommendation of Fakoya and Van Der Poll (2013) to integrate the ERP database systems with MFCA. The integration will allow companies to generate waste information that is essential to support their waste-reduction decisions. Second, companies need to introduce performance evaluation based on MFCA, and this evaluation should be monitored and discussed frequently within the company through staff meetings and performance reviews. Other research studies that make MFCA a primary focus include Hyrslova, Palasek, and Vagner (2011) and Schmidt and Nakajima (2013). Both studies proved that the MFCA method improves the traditional accounting systems by identifying the cost of material losses. towards a more effective production and positive environmental performance.

EMA has also been considered a holistic approach for evaluating the environmental implications of products and processes and presents accountants and managers with a focus for long-term assessment of costs associated with products, rather than short-term operating costs (Parker, 2000). Together with LCA and LCC, EMA helps to provide a means for identifying and evaluating environmental burdens in the various stages of a product's full life cycle ${ }^{1}$, beginning with raw material acquisition, through the manufacturing process, transportation and distribution, product use and reuse, and finally to product recycling and disposal by consumers (Kreuze \& Newell, 1994). This "cradle-to-grave" approach enables the firm to recognize the sources of pollution and determine the opportunities for minimizing environmental damage at any point of product stages (Hunkeler \& Huang, 1996). All descriptions of EMA as discussed above show that the practice leads to improved procedures and strategies for environmental performance consistent with the recommendation of NRBV. This helps to identify opportunities in the accounting system to build the business case for change.

Table 2.1 Available case studies addressing EMA tools for management

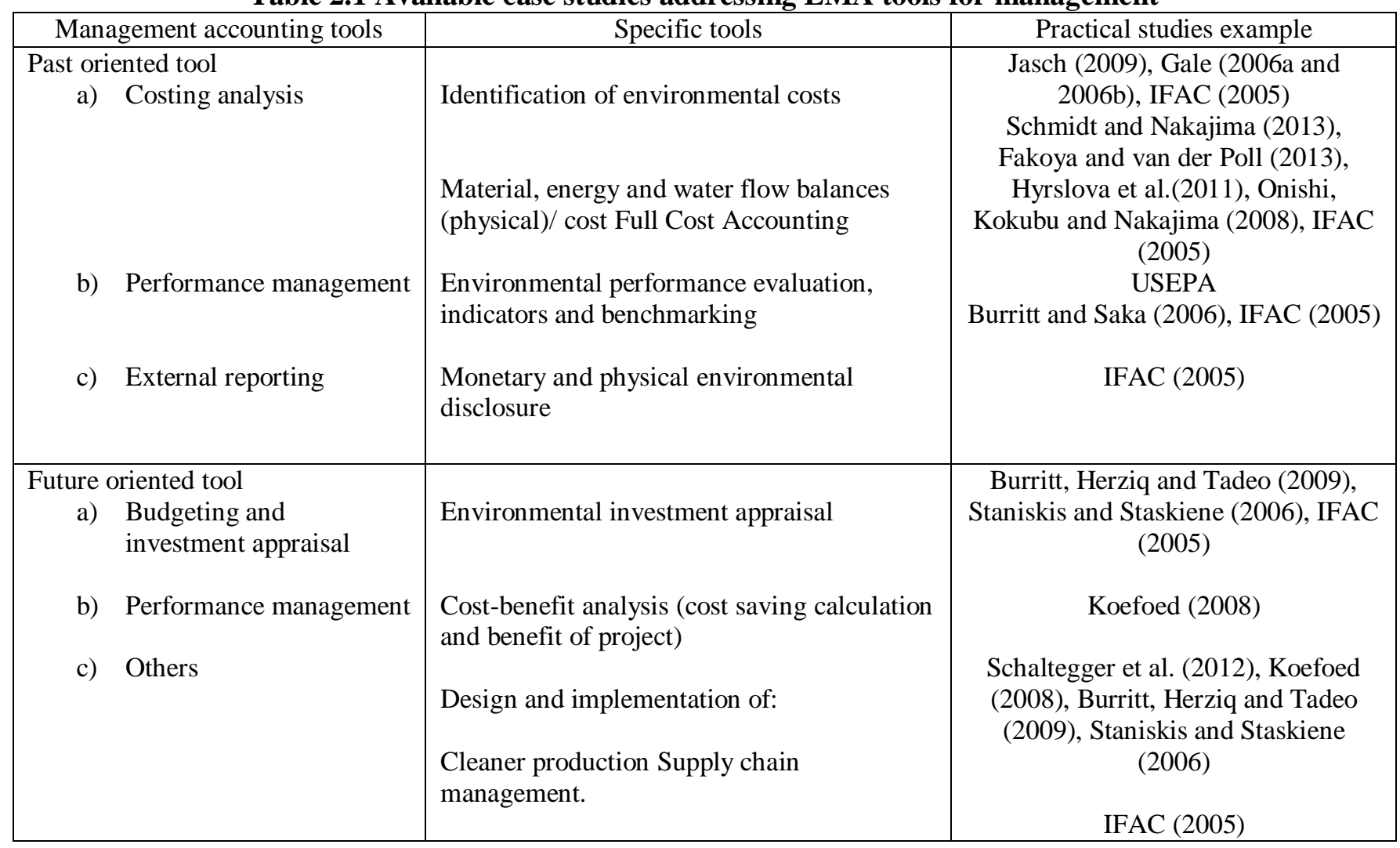

${ }^{1}$ A full product life cycle consisting of manufacturing, use and recycling stage, with each of these stages carries environmental loads which contribute to environmental effects such as smoke, greenhouse effect, waste etc. (Nagel, 2003). 
Table 2.2 Studies on EMA adoption in various countries

\begin{tabular}{|c|c|}
\hline Authors & Topics and method \\
\hline $\begin{array}{l}2002 \\
\text { Reyes }\end{array}$ & $\begin{array}{l}\text { - } \quad \text { Case study in the Philippines } \\
\text { - Discusses EMA's promotion by Philippines Institute of } \\
\text { Certified Public Accountants (PICPA) }\end{array}$ \\
\hline $\begin{array}{l}2003 \\
\text { Thy }\end{array}$ & $\begin{array}{l}\text { - } \quad \text { Case study in Denmark } \\
\text { - } \quad \text { Discusses the evaluation of Green Accounts requirement } \\
\text { introduced by the government }\end{array}$ \\
\hline $\begin{array}{l}2003 \\
\text { Burritt, Schaltegger, } \\
\text { Kokubu and Wagner }\end{array}$ & $\begin{array}{l}\text { - } \quad \text { Survey of listed companies in Australia, Japan and Germany } \\
\text { - } \quad \text { Focuses on the use of EMA for assessment of environmental } \\
\text { performance measure and staff appraisal } \\
\text { - } \quad \text { Similarities and differences between countries are examined }\end{array}$ \\
\hline $\begin{array}{l}2003 \\
\text { Jasch }\end{array}$ & $\begin{array}{l}\text { - Case study in Austria, discussing identification of } \\
\text { environmental cost through EMA }\end{array}$ \\
\hline $\begin{array}{l}2004 \\
\text { Xiaomei }\end{array}$ & $\begin{array}{l}\text { - } \quad \text { Case study in China } \\
\text { - Discusses governmental efforts on EMA and problems of } \\
\text { EMA implementation }\end{array}$ \\
\hline $\begin{array}{l}2005 \\
\text { Venturelli and Pilisi }\end{array}$ & $\begin{array}{l}\text { - Case study of pilot implementation of EMA in small medium } \\
\text { sized companies (SMEs) in Italy }\end{array}$ \\
\hline $\begin{array}{l}2005 \\
\text { Lee, Jung and Kim }\end{array}$ & - Case study based on pilot project in Korea \\
\hline $\begin{array}{l}2005 \\
\text { Scavone }\end{array}$ & $\begin{array}{l}\text { - } \quad \text { Case study on pilot project in Argentina } \\
\text { - } \quad \text { Focuses on CP in combination with EMA }\end{array}$ \\
\hline $\begin{array}{l}2005 \\
\text { Hyrslova and Hajek }\end{array}$ & $\begin{array}{l}\text { Qualitative study based on interviews with companies } \\
\text { registered in EMAS program in the Czech Republic } \\
\text { Discusses the state of preparedness of enterprises to } \\
\text { implement EMA }\end{array}$ \\
\hline $\begin{array}{l}2006 \\
\text { Jasch }\end{array}$ & $\begin{array}{l}\text { - Case study and company workshops within the Styrian } \\
\text { automobile cluster in Austria } \\
\text { - Discusses how to do environmental management cost } \\
\text { assessment }\end{array}$ \\
\hline $\begin{array}{l}2006 \\
\text { Gale }\end{array}$ & $\begin{array}{l}\text { - } \quad \text { Case study at a paper mill site in Australia } \\
\text { - } \quad \text { Discusses EMA framework applied on annual financial reports }\end{array}$ \\
\hline $\begin{array}{l}2006 \\
\text { Burritt and Saka } \\
2009 \\
\text { Burritt et al. } \\
2011 \\
\text { Hyrslova et al. } \\
2012 \\
\text { Schaltegger et al. } \\
2013 \\
\text { Fakoya and van der Poll } \\
2013 \\
\text { Schmidt and Nakajima }\end{array}$ & $\begin{array}{l}\text { - } \text { Case study in Japan, looking at EMA and eco-efficiency } \\
\text { - } \text { Case study at a rice mill company in Philipines } \\
\text { - } \text { Focuses on EMA for CP } \\
\text { - } \text { Case study at a ceramic manufacturing company in Czech } \\
\text { - } \text { Republic } \\
\text { - } \text { Focus on MFCA } \\
\text { - } \quad \text { Focuses on EMA for CP } \\
\text { - } \text { Case study at brewer company in South Africa } \\
\text { - } \text { Focus on the integration of ERP and MFCA } \\
\text { - Case study at manufacturing companies in Japan } \\
\text { - } \quad \text { Focus on MFCA }\end{array}$ \\
\hline
\end{tabular}

All the mentioned studies in Table 2.1 and 2.2 indicate system. Many of these studies are prescriptive, most that the systematic application of EMA methodology provides employing a case study approach. The samples used in each a better record of cost, acts as a catalyst in promoting study are limited; so too are the settings in which the studies environmental management activities, and is becoming an are conducted. The focus of tools is diverse, with the integral part of any successful environmental management consequences, problems, and challenges being viewed through 
a limited number of companies. Thus, further research should be conducted on EMA with a wider scope with consistent focus, so that results can be generalized sufficiently to be representative of EMA implementation.

\subsection{Theoretical perspective of EMA and environmental performance \\ Even though the motivations for corporate} environmental management, such as environmental policy, environmental innovation or other environmental activities may serve several objectives (for example, to increase firm value, to adhere to a code of ethics or to reduce business risks (Reinhardt, 2000), environmental performance should be the first and genuine focus of such efforts (Figge \& Hahn, 2012; Prajogo, Tang \& Lai, 2012). Reinhardt (2000) suggests that corporate environmental management promotes organizational learning by allowing the firm to obtain more factual information about the environmental impacts of particular processes, understanding customers' and regulators' attitudes towards the environment, or resolving how to put an environmental management system in place so that it can support continuous learning. This argument is consistent with the suggestion of Porter and van der Linde (1995), who assert that any innovation in response to environmental regulation will make organizations better equipped to deal with pollution once it occurs, including the processing of toxic materials and emissions and the reduction of the amount of toxic or harmful material generated (or converted into saleable forms), and how to improve secondary treatment. It simultaneously improves the affected products/processes (Porter \& van der Linde, 1995). The potential role of EMA in improving a firm's environmental performance may be explained through the perspective of Natural-Resource-Base-View (NRBV). NRBV takes the perspective that valuable, costly-to-copy firm resources and capabilities are the key sources of sustainable competitive advantage (Hart, 1995, p.986).

NRBV suggests that environmental benefits are realized first before a firm can expect to gain other economic benefits (Prajogo et al., 2012). There are three interconnected strategies recommended by NRBV: pollution prevention, product stewardship, and sustainable development. These strategies, which focus on waste and emission reduction and the development of new technologies, help the firm to produce a set of unique routines and procedures in environmental management that cannot be easily replicated by other firms, which in turn is a source of the firm's competitive advantage (Hart, 1995; Prajogo et al., 2012). NRBV proposes that competitive advantage and strategy are derived from a firm's capability to facilitate environmental activities (Hart, 1995). Therefore, the integration of an EMA system with other management tools may provide procedures and continuous improvements as suggested by NRBV, greatly supporting environmental management and an excellent strategy for improving environmental performance. The previous section has explained the use of EMA with various tools like CP, MFCA, and others which helps the firms to measure in monetary terms different environmental impacts identified in organizations and promotes positive change within environmental initiatives. EMA captures the true costs of waste and pollution in current processes and led firms to carry out good environmental practices such as pollution prevention, waste minimization, recycling, and re-using of waste resources as a new product (Mohr-Swart, Coetzee \& Blignaut, 2008). These are all parallel with the concept brought by the NRBV.

\subsection{Theoretical perspective of EMA and economic}

\section{performance}

There has been debate on the issue of whether initiatives to improve corporate environmental performance will or will not have an impact on the firm's economic performance. Previous studies that investigate the matter have provided inconclusive results so far, with some scholars finding a positive relationship between environmental and economic performance, and others finding a negative result (Horvathova, 2010). The mixed results can be attributed to two underpinning positions, namely "traditionalist" and "revisionist".

The first type of result, which claims that improving environmental performance will not increase the financial performance of a firm (negative relationship), is consistent with what Wagner, Phu, Azomahou, and Wehrmeyer (2002) term the "traditionalist" view of environmental activities. According to this view, the consequence of environmental management activities is increased production costs, which reduces the firm's profitability. Supporters of this view believe that environmental management involves a trade-off between the environment and economic performance, where the cost of prevention or cleanup is assumed to lead to higher prices and reduced competitiveness (Porter \& van der Linde, 1995a). With such an understanding, rational managers will try to minimize and delay environmental costs as much as possible, thus hindering the implementation of any innovations. Studies such as those by Wagner and Schaltegger (2004), Wagner et al. (2002), and Jaggi and Freedman (1992) found a negative relationship between environmental and economic performance, with all concluding that environmental efforts of the firm will not lead to a win-win outcome for their business. This conventional view remains prevalent among most managers (Burritt, 2004; Feldman, Soyka \& Ameer, 1996).

However, Porter and van der Linde (1995a) challenge the traditionalist view that posits a negative relationship between a firm's environmental management and economic performance and forward an argument they call a "revisionist" view. These authors, who based their claim on the reasoning of innovation offsets, argue that firms that innovate to meet regulatory requirements can offset their spending on 
environmental activities by allowing the companies to better use their inputs, create better products, or improved product yields. Such enhanced resource productivity is said to make companies more competitive (Porter \& van der Linde, 1995a). Moreover, the source of competitiveness at the industry level has been shifting towards superior productivity either in terms of lower costs than rivals or the ability to offer products with the superior value that justify a premium price. In this way, they rationalize firms' innovative efforts (Porter \& van der Linde, 1995b). Studies that found a positive relationship between environmental performance and economic performance; Klassen and McLaughlin (1996), Hart and Ahuja (1996), and King and Lenox (2001) all proved that it really "pays to be green". A more recent study by Burnett and Hansen (2008) and Al-Tuwaijri, Christensen, and Hughes (2004) confirm that proactive environmental management will result in reduced pollution and help the firm to reap economic benefits. Al-Tuwaijri et al. (2004) also suggest that good environmental performance is associated with more extensive use and disclosure of pollution measures. The positive relationship between environmental and economic performance has even been found in the context of the banking industry, which is deemed a sector that has a less environmental impact (Simpson \& Kohers, 2002).

Adding to the claim of the revisionists, other views justify the notion of the positive impact of environmental management on economic performance. According to Klassen and MacLaughlin (1996), the relationship between the two can be explained through both market (revenue) and cost pathways. On the revenue side, customers demonstrate their preferences for environmentally-oriented companies who make efforts to minimize the negative environmental impacts of their products and processes, recycling post-consumer waste, and establishing environmental management systems. This is particularly true as societies are increasingly concerned about the natural environment, with many recent studies showing that customers are willing to pay more for environmentally safe products (Dawkins \& Lewis, 2003; Maignan,2001; Mohr, Webb \& Harris., 2001). Consequently, environmentally responsible companies are in a strong position to expand their markets or displace competitors that fail to promote strong environmental performance. On the cost side, firms that invest heavily in environmental management systems and safeguards can potentially experience cost savings which include a lower cost structure, the avoidance of future environmental spills, crises, and liabilities. They can also experience greater productivity due to reduced energy and material consumption, materials waste, and inefficient processes (Klassen \& McLaughlin, 1996). Pollution is a form of economic waste, with any scrap, harmful substances or energy discharged into the environment being an incomplete, inefficient, and ineffective use of resources (Porter \& van der Linde, 1995a).
At the same time, such resources involve a high cost of handling, storage, and disposal by the firms (Jasch, 2009). Therefore, any pollution reduction can increase the economic efficiency of the firm (Burnett, 2008; King \& Lenox, 2002; Porter \& van der Linde, 1995a).

From another point of view, environmental performance can reduce the business's overall risk (Crowther \& Martinez, 2007; Feldman et al., 1996). Feldman et al. (1996) found that firms who improve their environmental management systems experienced an improvement in actual environmental performance which further led to an increase in the stock price by as much as five percent. Thus, the authors believe that environmentally sound corporations can improve their environmental risk profile, and the signaling of such performance can reduce the firm's systematic risk (Beta). However, the authors emphasize that to achieve this outcome, environmental management should be approached systematically, with the objectives clearly defined and a formal strategy developed. The findings of a more recent study by Najjar and Anfimiadou (2012) were consistent with the results of others, supporting the argument that eco-efficient activities are valued by shareholders and that firms having environmental policies have higher market values than those lacking environmental strategies.

A further view that relates firm economic performance to the natural environment is the Natural- Resource-BasedView (Hart, 1995). As discussed in the previous section, NRBV provides a theory of competitive advantage based on firms' commitment to an environmental challenge (Hart, 1995). Firms' capabilities in facilitating environmentally sustainable economic activity are said to lead the firm to have sustained competitive advantages such as lower production costs, longterm profit, and the pre-empting of competitors (Hart, 1995). Prajogo et al. (2012), who subscribe to NRBV, empirically prove that the adoption of EMS affects the economic welfare of the firm. Clarkson, Li, Richardson, and Vasvari (2011), who conducted a longitudinal analysis in the four most polluting industries in the US, found that firms' improvement of environmental performance in a prior period will lead to improved financial performance in the subsequent period. The study also points out that proactive environmental strategy cannot be easily mimicked by others, thus providing a sustained competitive advantage to a particular firm. Nishitani (2011) and Nishitani and Kokubu (2012) suggest that EMS implementation increases Japanese firms' economic condition through an increase in demand and improvement in productivity. In addition to this, environmentally concerned companies can build their reputation and good corporate image, which are considered important intangible resources for competitive advantage (Chang, 2011; Orsato,2006; Russo \& Fouts, 1997). Russo and Fouts (1997), who developed a model based on this view, found that improved environmental 


\section{CCenter for Promoting Education and Research (CPER) USA}

WWW.cpernet.org

performance can enhance a firm's pro-environment reputation, which is an inimitable resource that further enhances the firm's profitability. Orsato (2006) found a consistent result, as his study shows that the acknowledgment of environmental efforts such as EMS certification has now become a "license for the firm to operate" in the industry as it influences the firm's image and will eventually affect the buying behavior of consumers.

\subsection{CONCLUSION AND SUGGESTION FOR FUTURE RESEARCH}

Prior EMA studies have made limited use of a theory that attempts to explain EMA adoption. Most research has focused on descriptive and conceptual work (Christ \& Burritt, 2014; Contrafatto,2014). Most of the research done in this area involves case studies that measure both direct and indirect innovation (EMA) benefits. Thus, the data we have about the consequences are rather "soft", making it difficult for us to generalize about these consequences (Rogers, 2003). According to Christ and Burritt (2014, p.11), researchers seem to be unwilling to move beyond action-based case studies in further developing EMA. The authors raise a concern on the need for theoretical explanation and the use of a survey, interview, and statistical research methods to supplement case studies. Therefore, this paper intends to examine the theory that lies behind the assumptions of EMA consequences. All sections of this paper discussed the importance of EMA and how it can be linked to business performance. We have also discussed on some theory that may be underpinning the causal relationship between the two names, the NRBV, traditionalist view and revisionist view, which has been absent or been limitedly discussed by the previous literature. By this, it is hoped that future research could consider all these perspectives and develop an index of business performance that includes both economic and environmental performance of a firm and test them so that we can have imperical proofs on the consquences of EMA implementation.
Besides this, the second gap has been identified about the adverse consequences of EMA. Despite all the success stories, many firms are still reluctant to take a more proactive approach to EMA, perhaps due to a perceived lack of evidence that the benefits exceed the costs of pursuing these initiatives. The findings so far may not be generalizable since they are based on descriptive statistics rather than rigorous hypothesis testing. In addition to that, the mixed results on the relationship between environmental and economic performance, as well as the low adoption rate of EMA reported in previous literature, raises concern about the associated benefits of EMA use. This indicates that applying EMA is not without problems or challenges. Some studies show that problems might appear and prevent EMA to function at maximum performance. Some companies that have implemented EMA methodologies even discontinue implementing them (Kumpulainen \& Poohjola,2008). EMA was found not to be value-adding for some adopters, and behavioral constraints have obstructed the smooth operation of the practice (Chang \& Deegan, 2008; Gale, 2006a; Kumpulainen \& Pohjola, 2008). These problems and challenges reported by a few companies having a pilot EMA project in their organization indirectly tell us that EMA implementation may also lead to unintended consequences and the method itself might have weaknesses that we do not realize, and which are worthwhile to be examined. According to Rogers (2003), the consequences are not one-dimensional, but can take many forms: desirable versus undesirable, direct versus indirect, and anticipated versus unanticipated. Change agents generally do not anticipate negative consequences and often assume that the adoption of a given innovation will produce mainly beneficial results for adopters (Abrahamson, 1991; Rogers, 2003). Realizing this, and with a paucity in the diffusion literature focusing on this area (Rogers, 2003), future research should also extend the investigation to identify both positive and negative consequences of EMA implementation, together with the problems and challenges.

\section{REFERENCES}

Abrahamson, E. (1991). Managerial Fads and Fashions: The diffusion and rejection of innovations. Academy of Management Review, 16(3), 586-612.

Albelda, E. (2011). The role of management accounting practices as facilitators of the environmental management: Evidence from EMAS organisations. Sustainability Accounting, Management and Policy Journal, 2(1), 76100.

Al-Najjar, B., and Anfimiadou, A. (2012). Environmental policies and firm value. Business Strategy and the Environment, 21(1), 49-59.

Al-Tuwaijri, S.A., Christensen, T.E., and Hughes K.E. (2004). The relations among environmental disclosure, environmental performance and economic performance: A simultaneous equations approach. Accounting, Organizations and Society, 29(5-6), 447-471.

Askarany, D., and Smith, M. (2004). Contextual factors and administrative changes. Journal of Issues in Informing Science and Information Technology, 1, 179-188. 


\section{(C) Center for Promoting Education and Research (CPER) USA}

www.cpernet.org

Burnett, R. D., and Hansen, D. R. (2008). Ecoefficiency: Defining a role for environmental cost management. Accounting, Organizations and Society, 33(6), 551-581.

Burritt, R.L. (2004). Environmental Management Accounting: Roadblocks on the way to the green and pleasant land. Business Strategy and the Environment, 13(1), 13-32.

Chang, C.H. (2011). The influence of corporate environmental ethics on competitive advantage: The mediation role of green innovation. Journal of Business Ethics, 104(3), 361-370.

Chang, H.C., and Deegan, C. (2008). Environmental Management Accounting and environmental accountability within universities: Current practice and future potential. In Schaltegger, S., Bennett, M., Burritt, R.L, and Jasch, C. (Eds), Environmental Management Accounting for cleaner production (301-320). The Netherlands: Springer.

Christ, K.L., and Burritt, R.L. (2013). Environmental management accounting: the significance of contingent variables for adoption. Journal of Cleaner Production, 41, 163-173.

Christ, K.L., and Burritt, R.L. (2014). Material flow cost accounting: A review and agenda for future research. Journal of Cleaner Production, 41, 1-12.

Christ, K.L., and Burritt, R.L. (2014). Material flow cost accounting: A review and agenda for future research. Journal of Cleaner Production, 41, 1-12.

Clarkson, P. M., Li, Y., Richardson, G. D., and Vasvari, F. P. (2011). Does it really pay to be green? Determinants and consequences of proactive environmental strategies. Journal of Accounting and Public Policy, 30(2), 122-144.

Contrafatto, M. (2014). The institutionalization of social and environmental reporting: An Italian narrative. Accounting, Organizations and Society, 39(6), 414-432.

Crowther, D., and Martinez, E.O. (2007). Current debates in corporate social responsibility: An agenda for research. Issues in Social and Environmental Accounting, 1(1), 26-39.

Dawkins, J., and Lewis, S. (2003). CSR in stakeholder expectations: And their implication for company strategy. Journal of Business Ethics, 44(2-3), 185-193.

Doorasamy, M., and Garbharran, H. (2015). The role of Environmental Management Accounting as a tool to calculate environmental costs and identify their impact on a company's environmental performance. Asian Journal of Business and Management, 3(1).

Fakoya, M.B., and van der Poll, H.M. (2013). Integrating ERP and MFCA systems for improved waste-reduction decisions in a brewery in South Africa. Journal of Cleaner Production, 40, 136-140.

Farizah, S., Maliah, S. and Norhayati, M.A. (2015). Material Flow Cost Accounting (MFCA) enablers and barriers: The case of a Malaysian small and medium-sized enterprise (SME). Journal of Cleaner Production, 108, 1365-1374.

Feldman, S.J., Soyka, P.A. and Ameer, P. (1996). Does Improving a Firm's Environmental Management System and Environmental Performance Result in a Higher Stock Price? Working Paper Fairfax. VA: ICF Kaiser International.

Figge, F., and Hahn, T. (2012). Is green and profitable sustainable? Assessing the trade-off between economic and environmental aspects. International Journal of Production Economics, 140(1), 92-102.

Frondel, M., Horbach, J., and Rennings, K. (2007). End-of-pipe or cleaner production? An empirical comparison of environmental innovation decisions across OECD countries. Business Strategy and the Environment, 16(8), 571-584.

Gadenne, D., and Zaman, M. (2002). Strategic environmental management accounting: An exploratory study of current corporate practice and strategic intent. Journal of Environmental Assessment Policy and Management, 4(2), 123-150.

Gale, R. (2006a). Environmental costs at a Canadian paper mill: A case study of Environmental Management Accounting (EMA). Journal of Cleaner Production, 14(14), 1237-1251.

Gale, R. (2006b). Environmental Management Accounting as a reflexive modernization strategy in cleaner production. Journal of Cleaner Production, 14(14), 1228-1236.

Hart, S.L. (1995). A natural-resource based view of the firm. Academy of Management Review, 20(4), 986-1014.

Hart, S.L., and Ahuja, G. (1996). Does it pay to be green? An empirical examination of the relationship between emission reduction and firm performance. Business Strategy and the Environment, 5(1), 30-37.

Horvathova, E. (2010). Does environmental performance affect financial performance? A meta-analysis. Ecological Economics, $70(1), 52-59$.

Hyrslova, J., and Hajek, M. (2005). Environmental management accounting in the framework of EMAS II in the Czech 
Republic. In Rikhardsson, P.M., Bennett, M., Bouma, J.J. and Schaltegger, S. (Eds), Implementing Environmental Management Accounting: Status and challenges (279-296). The Netherlands: Springer.

Hyrslova, J., and Hajek, M. (2006). Environmental management accounting in Czech companies that have implemented environmental management systems. In Schaltegger, S., Bennett, M. and Burritt, R. (Eds), Sustainability accounting and reporting (433-456). Dordrecht: Springer.

Hyrslova, J., Palasek, J., and Vagner, M. (2011). Material flow cost accounting (MFCA) - tool for the optimization of corporate production processes. Business, Management and Education, 1, 5-18.

Iraldo, F., Testa, F., and Frey, M. (2009). Is an environmental management system able to influence environmental and competitive performance? The case of eco-management and audit scheme (EMAS) in the European union. Journal of Cleaner Production, 17(16), 1444-1452.

Jaggi, B., and Freedman, M. (1992). An examination of the impact of pollution performance on economic and market performance: Pulp and paper firms. Journal of Business Finance and Accounting, 19(5), 697-713.

Jasch, C. (2009). Environmental and Material Flow Cost Accounting: Principles and procedures. The Netherlands: Springer.

King, A.A, Lenox, M., and Terlaak, A. (2005). The strategic use of decentralized institutions: Exploring certification with the ISO 14001 management standard. Academy of Management Journal, 48(6)1091-1106.

Kreuze, J. G., and Newell, G. E. (1994). ABC and life-cycle costing for environmental Expenditures. Management Accounting, 65(8), 38-42.

Kumpulainen, A., and Pohjola, T. (2008). Success factors in developing EMA - Experiences from four follow-up case studies in Finland. In Schaltegger, S., Bennett, M., Burritt, R.L, and Jasch, C. (Eds), Environmental Management Accounting for cleaner production (477-490). The Netherlands: Springer.

Maignan, I. (2001). Consumers' perceptions of corporate social responsibilities: A cross-cultural comparison. Journal of Business Ethics, 30(1), 57-72.

Mohr, L.A., Webb, D.J., and Harris, K.E. (2001). Do consumers expect companies to be socially responsible? The impact of corporate social responsibility on buying behavior. Journal of Consumer Affairs, 35(1), 45-72.

Morrow, D., and Rondinelli, D. (2002). Adopting corporate Environmental Management Systems: Motivations and results of ISO 14001 and EMAS certification. European Management Journal, 20(2), 159-171.

Nishitani, K. (2011). An empirical analysis of the effects on firms' economic performance of implementing Environmental Management Systems. Environmental and Resource Economics, 48(4), 569-586.

Nishitani, K., and Kokubu, K. (2012). Why does the reduction of greenhouse gas emissions enhance firm value? The case of Japanese manufacturing firms. Business Strategy and the Environment, 21(8), 517-529.

Onishi, Y., Kokubu, K., and Nakajima, M. (2008). Implementing material flow cost accounting in a pharmaceutical company. In Schaltegger, S., Bennett, M., Burritt, R.L, and Jasch, C. (Eds), Environmental Management Accounting for cleaner production (395-410). The Netherlands: Springer.

Orsato, R.J. (2006). When does it pay to be green? California Management Review, 48(2), 128.

Parker, L.D. (2000). Environmental costing: A path to implementation. Australian Accounting Review, 10(3), 1-20.

Parker, L.D. (2005). Social and environmental accountability research: A view from the commentary box. Accounting, Auditing and Accountability Journal, 18(6). 842-60.

Perez, E.A., Ruiz, C.C., and Fenech, F.C. (2007). Environmental Management Systems as an embedding mechanism: A research note. Accounting, Auditing and Accountability Journal, 20(3), 403-422.

Porter, M.E., and van der Linde, C. (1995a). Green and competitive: Ending the stalemate. Harvard Business Review, 73(5), 120-134.

Porter, M.E., and van der Linde, C. (1995b). Toward a new conception of the environment competitiveness relationship. The Journal of Economic Perspectives, 9(4), 97- 118.

Prajogo, D., Tang, A.K., and Lai, K.H. (2012). Do firms get what they want from ISO 14001 adoption? An Australian perspective. Journal of Cleaner Production, 33, 117-126.

Reinhardt, F.L. (1998). Environmental product differentiation: Implications for corporate strategy. California Management Review, 40(4), 43-73.

Reinhardt, F.L. (2000). Down to earth: Applying business principles to environmental management. Harvard Business Press. Rogers, E.M. (2003). Diffusion of Innovation, (5 ${ }^{\text {th }}$ edn.). New York: Free Press. 
Russel, W.G., Skalak, S.L., and Miller, G. (1994). Environmental cost accounting: The bottom line for environmental quality management. Environmental Quality Management, 3(3), 255-268.

Russo, M.V., and Fouts, P.A. (1997). A resource-based perspective on corporate environmental performance and profitability. Academy of Management Journal, 40(3), 534-559.

Schaltegger, S., Bennett, M., Burritt, R.L, and Jasch, C. (2008). Environmental Management Accounting (EMA) as a support for Cleaner Production. In Schaltegger, S., Bennett, M., Burritt, R.L, and Jasch, C. (Eds), Environmental Management Accounting for cleaner production (477-490). The Netherlands: Springer.

Schaltegger, S., Gibassier, D., and Zvezdov, D. (2011). Environmental Management Accounting: A bibliometric literature review. CSM, Centre for Sustainability Management.

Schmidt, M., and Nakajima, M. (2013). Material flow cost accounting as an approach to improve resource efficiency in manufacturing companies. Resources, 2(3), 358-369.

Simpson, W.G., and Kohers, T. (2002). The link between corporate social and financial performance: Evidence from the banking industry. Journal of Business Ethics, 35(2), 97-109.

Staniskis, J.K, and Stasiskiene, Z. (2006). Environmental Management Accounting in Lithuania: Exploratory study of current practices, opportunities and strategic intents. Journal of Cleaner Production, 14(14), 1252-1261.

United States Environmental Protection Agency (USEPA) (1995). An introduction to environmental accounting as a business management tool: Key concepts and terms. Washington D.C: Office of Pollution Prevention and Toxics.

Wagner, M., Van Phu, N., Azomahou, T., and Wehrmeyer, W. (2002). The relationship between the environmental and economic performance of firms: An empirical analysis of the European paper industry. Corporate Social Responsibility and Environmental Management, 9(3), 133-146. 